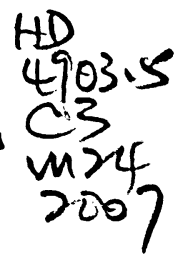

\title{
HEARING AUDIBLE MINORITIES: \\ ACCENT, DISCRIMINATION, AND THE INTEGRATION OF IMMIGRANTS INTO THE CANADIAN LABOUR MARKET
}

by

Alanna MacDougall, BA, Carleton University, 2002

\author{
A Major Research Paper \\ presented to Ryerson University \\ in partial fulfillment of the requirements for the degree of \\ Master of Arts \\ in the Program of \\ Immigration and Settlement Studies
}

Toronto, Ontario, Canada, 2007

(C) Alanna MacDougall 2007 
UMI Number: EC53439

\section{INFORMATION TO USERS}

The quality of this reproduction is dependent upon the quality of the copy submitted. Broken or indistinct print, colored or poor quality illustrations and photographs, print bleed-through, substandard margins, and improper alignment can adversely affect reproduction.

In the unlikely event that the author did not send a complete manuscript and there are missing pages, these will be noted. Also, if unauthorized copyright material had to be removed, a note will indicate the deletion.

\section{$\mathrm{UMI}^{\circ}$}

UMI Microform EC53439

Copyright 2009 by ProQuest LLC

All rights reserved. This microform edition is protected against unauthorized copying under Title 17, United States Code.

ProQuest LLC

789 East Eisenhower Parkway

P.O. Box 1346

Ann Arbor, MI 48106-1346 
I hereby declare that I am the sole author of this major research paper.

I authorize Ryerson University to lend this paper to other institutions or individuals for the purpose of scholarly research.

I further authorize Ryerson University to reproduce this paper by photocopying or by other means, in total or in part, at the request of other institutions or individuals for the purpose of scholarly research. 


\author{
HEARING AUDIBLE MINORITIES \\ Accent, discrimination, and the integration of immigrants \\ into the Canadian labour market \\ (C) Alanna MacDougall, 2007 \\ Master of Arts \\ Immigration and Settlement Studies \\ Ryerson University
}

\begin{abstract}
Accent is a permanent marker of difference for learners of a second language, and may be a barrier to finding appropriate employment. Research on discrimination and accent reveals a widespread belief in the myth of a standard, ideal accent. This has resulted in individuals stereotyping accented speakers and drawing inappropriate conclusions about their language ability, leading to discrimination in both the workplace and broader society. A small study of Ottawa companies conducted for this paper supports the hypothesis that some employers may rely on accent to determine an applicant's English proficiency. Accent discrimination can be addressed by providing employers with information about accent and appropriate tools for language evaluation, confronting the reality of accent discrimination with ESL students, and by broadening the discourse on discrimination as a whole to recognise that minorities can be audible as well as visible.
\end{abstract}

Key words:

audible minorities; accent; immigrants; discrimination; labour market 


\section{TABLE OF CONTENTS}

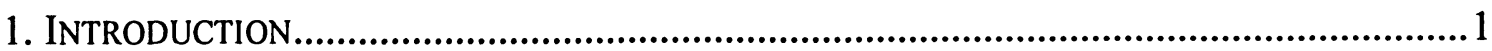

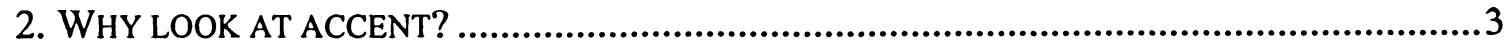

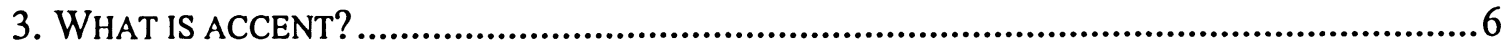

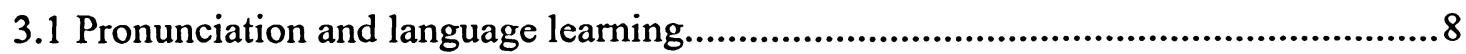

3.2 Accent and language ability ............................................................................... 10

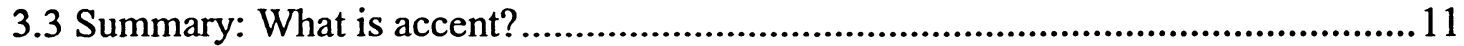

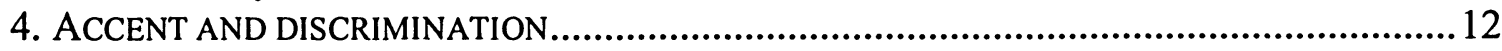

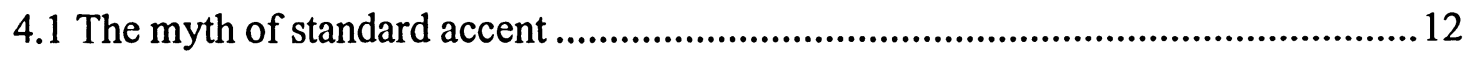

4.2 Accent and stereotypes ..................................................................................... 15

4.3 Accent and perception of language ability............................................................. 18

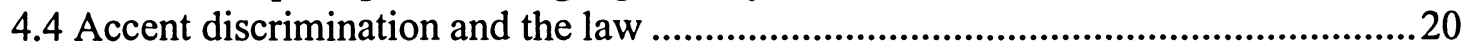

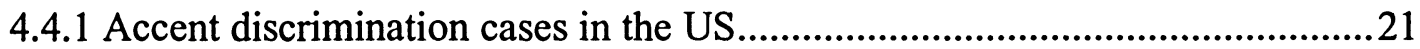

4.4.2 Accent discrimination cases in Canada...........................................................22

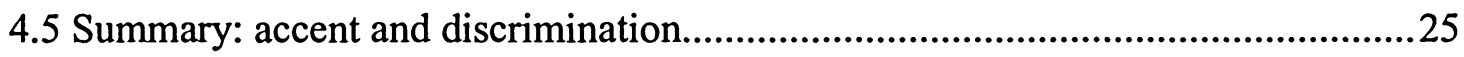

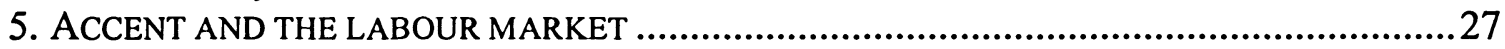

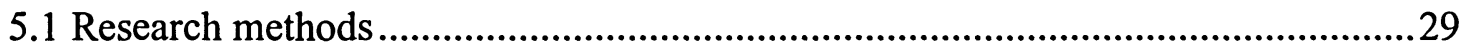



5.2.1 Job and respondent characteristics........................................................................

5.2.2 Declared methods of evaluation and attitudes towards language .....................33

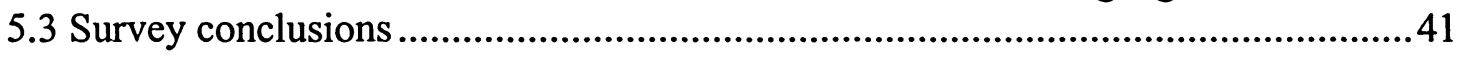

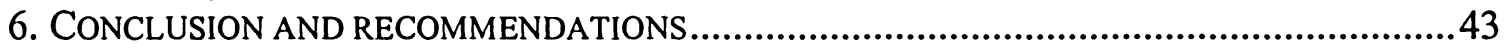

\section{List of Tables}

TABLE 1: Language use in position................................................33

TABLE 2: Methods of evaluation....................................................

TABLE 3: Perceived useful language training components..............................36

TABLE 4: Agreement with statements...............................................

List of Appendices

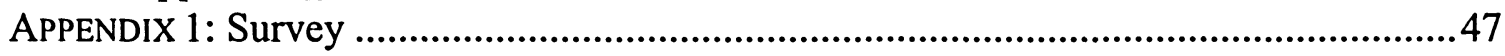

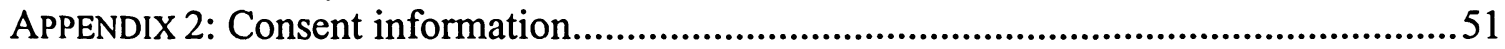

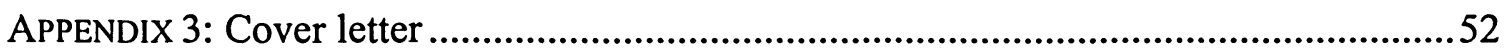




\section{INTRODUCTION}

Accent is a permanent marker of difference for learners of a second language. While language skills are a necessary and valid requirement for many jobs in the Canadian workplace, a distinction must be made between language ability and accent. A small study of Ottawa businesses indicates that employers may discriminate against accented applicants. The discourse on discrimination needs to be broadened to recognise that minorities can be audible as well as visible, and accented immigrants may experience discrimination in the labour market.

The following section of this paper describes why accent is a relevant and plausible barrier to labour market integration.

Section 3 looks at the notion of accent and why second language speakers will always have an accent, resulting in a permanent marker of difference. Though English as a Second Language (ESL) teachers are increasingly incorporating pronunciation training in classrooms, the efficacy of this training is questionable and its ability to eliminate foreign accent highly unlikely.

Section 4 describes the history of research on discrimination on the basis of accent, including the myth of languages having a 'standard accent,' psychological studies looking at stereotyping of accented speakers, and jurisprudence documenting real-world cases of accent discrimination. 
Section 5 discusses the results of my own research looking at how employers use accent to evaluate the language ability of job candidates. In a small study of Ottawa private sector companies, employers revealed a readiness to rely on accent as a factor in determining an applicant's English proficiency.

Finally, section 6 provides concluding remarks and recommendations for addressing accent discrimination, including: providing better information for employers about accent and resources on appropriate ways to evaluate language ability; discussing accent discrimination with students in ESL classrooms, and; incorporating accent into broader anti-discrimination and diversity initiatives. 


\section{WHY LOOK AT ACCENT?}

It should be a familiar story to those with an interest in the field of immigration that immigrants to Canada today have a more difficult time finding meaningful and relevant employment than they did in past decades, resulting in declining economic outcomes. But while numerous studies have established this phenomenon, the question of why remains unanswered.

Theories as to what is causing these declining economic outcomes for immigrants are numerous. Hypotheses range from greater diversity in source countries leading to immigrants having more varied and difficult to meet needs (Prefontaine \& Benson, 1999), foreign experience not being relevant in the Canadian labour market (Green \& Worswick, 2004), or even increased competition for jobs with better and better educated Canadians (Reitz, 1999). But while these theories speculate about how the characteristics of immigrants may inhibit labour market integration, this is only half of the story. Equally important to consider are the environment into which immigrants are trying to integrate, and arbitrary barriers put up by the labour market itself.

Looking at this question, Public Policy Forum recently conducted a study of Canadian employers (Lopes, 2004) asking what barriers they experienced to hiring newcomers. Interestingly, this study revealed that employers were reticent to hire immigrants due to concerns over their lack of Canadian experience and cultural fit, but that the most important barrier was the employer's perception of newcomers' language ability. While it is certainly valid that employers are preoccupied that potential candidates be qualified, 
suitable for the work environment, and capable of communicating effectively, it is important to deconstruct these concerns to determine the boundary between valid qualification requirements and arbitrary barriers created by employers. This boundary delineates fair hiring practices from discrimination.

As indicated by PPF and other research, the requirement for language ability may be one of the most difficult labour market barriers for immigrants to overcome (Prefontaine \& Benson, 1999, p. 19). Language requirements for jobs are valid and real, especially in the communication-driven service industry which today makes up three-quarters of the Canadian job market (Statistics Canada, 2006). Much discussion has taken place in recent years on the lack of language ability of many newcomers to Canada. Landing data show that in 2006 , as many as $33 \%$ of newcomers had no ability in either of Canada's official languages, and only 13\% spoke either English or French as a first language (Citizenship and Immigration, 2006a). But is language ability really an objective criterion, easily and fairly assessed by employers looking for workers with good communication skills?

This paper seeks to explore the extent to which immigrants' language ability may in fact be evaluated through a factor with little relation to fluency. Accent, often the first indication of a speaker's native or nonnative language status, is a permanent marker of linguistic difference for individuals who learn a second language in adulthood. An accented speaker may achieve native-like mastery in grammar and vocabulary, but stereotypes and assumptions about ability continue to be tied in the minds of many to pronunciation. 
As will be discussed in section 4.3, numerous laboratory studies conducted over the last half century have shown again and again that a listener's evaluation of a speaker can be affected by accent (e.g. Delamere, 1986; Giles ., 1995; Cargile et al., 1998). But the real world consequences of this stereotyping and discrimination are also significant, as accented immigrants continue to attempt integration into a labour market that is putting an increasing emphasis on language ability. For assessment of language to be fair for these job applicants, the difference between language ability and accent needs to be clear to both those making hiring decisions and the broader Canadian public. Because accent has not been part of the common discourse on prejudice, in the workplace or outside, it remains "the last back door to discrimination" (Lippi-Green, 1997, p. 73). 


\section{WHAT IS ACCENT?}

If all of the sounds that are used in all the languages of the world were put together, there would be well over a hundred different speech sounds. ${ }^{1}$ Many sounds would overlap across numerous languages, but it would be very unusual for two different languages to use exactly the same sounds. Children are capable of making all of these different sounds. As they age, however, they lose the ability to make sounds they do not hear or use. By the time adolescence is reached, the brain appears to 'lock-in' speech patterns, making it much more difficult to imitate sounds with which an individual is not familiar (Munro, 2003, p. 38; Pawlikowska-Smith, 2002, p. 29). ${ }^{2}$

The range of sounds available in a particular variety of a language and the way those sounds are used are called the language's phonology. For example, the phonology of English used by native speakers in Toronto has a limited number of sounds associated with it. If an adult from Toronto who had never been exposed to another phonology learned a second language, it would be hard for him or her to produce sounds in ways that were different from Toronto English phonology. A vowel sound in the new language that was a little bit higher or lower might get shifted to a vowel sound with which the Toronto native was already familiar. Moreover, a phonological rule that is used subconsciously in Toronto English might also be applied erroneously to the new language (e.g. a rule such

\footnotetext{
${ }^{1}$ The International Phonetic Alphabet denotes 107 distinct sounds as well as 56 diacretics and suprasegmentals which modify basic sounds, allowing for a large number of permutations of speech sounds that have been documented in world languages.

${ }^{2}$ No one really knows why new speech sounds are more difficult to learn after puberty. Some researchers posit that after puberty, a "lateralization" of the brain occurs or that a certain amount of brain plasticity is actually lost, while others argue that it may simply be an attitude change, that expectations and/ or motivation changes past a certain age (Celce-Murcia et al., 1996). All agree, however, that the phenomenon of a diminished ability to make new speech sounds past a time around puberty is real.
} 
as ' $\mathrm{t}$ ' sounds becoming ' $\mathrm{d}$ ' sounds when in between two vowels and after a stressed syllable, turning 'water' into 'wader' or 'potato' into 'potado'). When speaking that second language, his or her speech would bear the tell-tale signs of Toronto phonology, or the limited number of sounds and ways of using those sounds that the speaker's brain has determined are needed for language use and so have been 'locked in.' Conversely, if someone comes to Toronto from a place where a different phonology is used, the way they speak will also bear the tell-tale signs of his or her region of origin. Whether newcomers are from St. John's, Edinburgh, Moscow or Mexico City, their speech will be stamped with the range of sound use that makes up the phonology they themselves learned as a child.

Accent, therefore, is the subconscious application of a phonology to spoken language, revealed through the pronunciation of words. Foreign accent, evidenced in the pronunciation of nonnative speakers, is the subconscious application specifically of a mother tongue phonology to a second language.

Learning to pronounce an unfamiliar sound is certainly possible. Language learners and accent learners (e.g. someone from Toronto attempting an Australian accent) can acquire new speech sounds that aren't part of their own region's sound-vocabulary, or they can learn to use the same sounds they already use but in different places. Nevertheless, human ears are extremely sensitive to even slight differences in pronunciation when listening to a native language; only very rarely does someone learn a new language or accent later in life without any tell-tale signs of their original, childhood phonology 
(Munro, 2003, p. 38). In fact, we can pretty much say that anyone who learns a language as an adult will always have an accent. ${ }^{3}$

Picking up the accent of a new language, therefore, is not as simple as rearranging familiar sounds. It is a complex, largely subconscious process that is for the most part determined by phonology used in childhood.

\subsection{Pronunciation and language learning}

Not as obvious a part of language production as grammar and vocabulary, pronunciation has historically received less scholarly attention than these higher-profile linguistic features (Celce-Murcia et al., 1996). As such, pronunciation has also been given less emphasis in English as a Second Language (ESL) ${ }^{4}$ classrooms.

The traditional cognitive approach to language learning which rose to popularity in the 1960s de-emphasised pronunciation, arguing that the achievement of native-like proficiency was an unrealistic aim and so was best left out of ESL curricula (CelceMurcia et al., 1996). In recent years, however, ESL classrooms have shifted to a

\footnotetext{
${ }^{3}$ The reader may be able to think of examples of individuals who have mastered a second phonology, or even actors who can 'put on' a different accent in movies. It is important to remember that exposure in childhood to certain sounds will affect a person's ability to mimic them as an adult - an Australian who grew up watching Hollywood movies will have a much easier time speaking with an American accent than an adult American will have trying to speak with an Australian accent that she has just heard for the first time. Talented actors may also be able to teach themselves the phonology of an unfamiliar accent, but speaking scripted words for short periods of time between takes is a far cry from participating in a fluid and spontaneous conversation.

${ }^{4} \mathrm{ESL}$ is distinct from English as a Foreign Language (EFL), where English is learned without external submersion in an English environment (e.g. an English classroom in a Chinese high school). While pronunciation has been given equally little treatment in ESL and EFL classrooms, this section looks specifically at pronunciation in ESL curricula.
} 
communicative approach, stressing clear communication as a goal rather than technical mastery of a language. This emphasis on clarity rather than flawlessness appears to have resulted in a dramatic increase in pronunciation components for ESL learners in the last decade (Derwing et al., 1998, p. 394). But while pronunciation has been recognised as an important part of achieving clear communication, it remains acknowledged that the aim of teaching pronunciation should not be for ESL students to sound like native speakers. Such an objective would simply be impossible to achieve (Celce-Murcia et al., 1996, p. 8; Munro, 2003, p. 40).

The Centre for Canadian Language Benchmarks (CCLB), the organisation which sets federal language proficiency standards for Canadian immigrants, asserts that pronunciation teaching may be useful in improving intelligibility but that accent 'elimination' should not be proposed as either a goal or even a desirable outcome-ESL training centres which claim they can 'cure' a foreign accent are either dishonest or naïve. According to the CCLB's theoretical framework,

[a]ccent should not be treated as "pathology"; it is perfectly acceptable to have an accent (everybody has one), as long as speech intelligibility is not impaired. While remedial classes teaching global prosodic features of speech do make a difference in better intelligibility evaluations of learners' speech over time, selling adult ESL learners on the idea that an "accent" is and will continue to be a problem and an obstacle in achieving their goals may be, in some cases, ethically unclear. (Pawlikowska-Smith, 2002, p. 30.) 
Though increasingly popular, the usefulness of including pronunciation training in ESL classrooms remains under question. A number of studies looking at this issue (Purcell \& Suter, 1980; Macdonald et al., 1994) failed to find any clear improvement in pronunciation when ESL students were given pronunciation-specific training. A 1997 study by Derwing, Munro and Weibe showed that pronunciation training did result in improved intelligibility for some speakers, but positive results were eliminated when speakers uttered nonsensical sentences (e.g. "people eat through their noses", p. 234). In a 1998 follow-up study by the same authors, pronunciation training again appeared to have little effect, though classes including components on prosody (e.g. pitch and tempo) seemed to result in improved intelligibility. Even these two slightly more positive studies remain problematic, however, in that results were only measured for individuals reading short statements in a laboratory setting, not during natural flow of speech. Derwing, Munro and Weibe admit that there is "little evidence as to whether one focus of pronunciation instruction is superior to another or even whether any form of instruction is beneficial at all" (1998, p. 394).

\section{$\underline{3.2}$ Accent and language ability}

While studies have shown that 'elimination' of a foreign accent is nearly impossible and even training to 'reduce' accent may have limited value if any, it also must be stressed that accent bears no direct, consistent correlation with ability to function in a language. While some highly proficient ESL speakers are considered to have a strong foreign accent, others speakers considered to have less noticeable accents do not necessarily have a high level of proficiency (Pawlikowska-Smith, 2002, p. 28). This can be particularly 
problematic with children or especially talented mimickers of sound who, quickly picking up a new accent, cause native speakers to assume their language ability is greater than it is (Baker, 2003). At the same time, examples are numerous in academia and in the literary world of individuals who communicate and write at a level of communicative proficiency far beyond the average native speaker, though their speech is accented.

In short, as stated by the CCLB, "There is no systematic, one-to-one relationship between learners' clarity of pronunciation and their proficiency levels." (Pawlikowska-Smith, 2002, p. 28).

\subsection{Summarv: What is accent?}

Accent is the subconscious application of a phonology to spoken language and, in the case of nonnative speakers, is the subconscious application of a mother tongue's phonology to a second language. Everyone who learns a second language as an adult will have an accent. While ESL classes are increasingly paying attention to pronunciation, even a significant amount of pronunciation-specific training will never result in an individual being able to 'eliminate' an accent, and it is questionable whether classroom training can have any real effect at all. At the same time, studies have shown that there is no direct link between accent and language ability. 


\section{ACCENT AND DISCRIMINATION}

Recognising that an adult learner of a second language will always have an accent is of particular importance as we turn to look at accent and discrimination. While many listeners may erroneously consider accent a marker or indication of language ability, accent in adult second language learners is in fact a permanent marker of difference. While not visible or genetic such as skin colour, nor due to the lottery of birth like country of origin, accent is nevertheless an audible difference that sets the bearer apart, and can therefore serve as an excuse for discriminatory treatment (Munro, 2003, p. 39).

\subsection{The mvth of standard accent}

If accent is a system of pronunciation, then everyone has an accent. More often in common parlance, however, the word 'accent' is taken to mean a system of pronunciation that is different from a perceived norm. But this norm is not objectively constructed.

Groups and societies today and in the past have often given preference to certain systems of pronunciation. This preference does not stem from any inherent superiority of one accent over another or even one accent being more common or having deeper historical roots. Instead, preferred accents tend to achieve their status through politics and power; phonologies of groups with social or geographical prestige (e.g. Received Pronunciation or the 'Queen's English' in the UK, or the Beijing pronunciation of Mandarin in China) gain favour for the status they represent (Lindemann, 2003, p. 348). The notion of 'proper' accent, therefore, is a social construct rather than an objective concept. 
The myth that languages have one proper pronunciation to the exclusion of other phonologies has been attributed to the ideology of standard language, first described by Milroy and Milroy in 1985 (Lippi-Green, 1997, p. 166). In the North American context, standard language ideology has been defined by Rosina Lippi-Green as "a bias towards abstracted, idealized, homogenous spoken language, which is imposed and maintained by dominant institutions and which names as its model the written language, but which is drawn primarily from the spoken language of white, upper middle class Midwesterners" (1997, p. 64) with the "most salient feature" being "the goal of suppression of variation of all kinds" (1994, p. 166).

In her book English with an Accent (1997) Lippi-Green describes ways in which the myth of standard accent has been propagated. For example, children may learn to give preference to certain accents by being presented with differently accented characters in movies. Lippi-Green demonstrates this through a study of 24 Disney films released since the 1930s detailing how frequently antagonists are given foreign accents compared to protagonists who speak with standard 'American' accents, even when an American accent does not make sense for the character. A prime example is the movie Aladdin, in which the hero prince speaks with a Mid-Western American accent while the evil Vizier is given an Arabic accent, quite appropriate given the setting of the film but here used to heighten the audience's perception of his villainy. The message to children is clear: heroes sound American; distrust foreign accents. 
The myth of standard accent is also propagated in the adult world, for example through the standard newscaster accent. Looking at the illogical requirement that newscasters from across the United States speak with the same accent, Lippi-Green incorporates into standard language ideology Noam Chomsky's idea that the media must sell the myth of cultural homogeneity to justify its very trade (1997, p. 142). A national newscast portraying events of supposed homogenous national relevance in 22 minutes or less requires a standard-sounding broadcaster to complete the image of its significance. Allowing for accent diversity would only undermine the idea that daily events across and outside the country are simple and can be easily understood through the same short sound bites - no matter where the viewer is in the country. Why else, she argues, would a news organisation such as CNN be located in Atlanta, Georgia, squarely in the Southern United States, yet insist that all of its broadcasters speak as though reporting from the Mid-West? (idem.). More than 'selling' news, the newscaster accent also creates for adult viewers an archetypal accent for appropriate, informed speech.

Drawing on her legal background, Mari Matsuda (1991) also looks at the myth of standard accent. Matsuda makes a comparison with work done by feminist scholars and anti-discrimination advocates who have pointed out that, while the law purports to be neutral, the hidden norm is nevertheless male and white. Similarly, she argues that the notion of English ability may appear to be neutral, but in reality covers a hidden norm of native-spoken North American English (NAE). This, she says, sets up for failure those who do not conform to the myth of standard accent, either because they are unwilling or unable. Instead, the onus is placed on the non-standard speaker to 'fit in' rather than on 
society to accept different modes of speech. Matsuda in fact sees extremely negative and far-reaching consequences for a society that falls victim to the myth of standard language and standard accent, stating that

demand for speech uniformity suggests preference for conformity, distrust of difference, and attachment to a large, looming notion of "we." The demand for speech uniformity is scary, in the scary sense of statism, nationalism, territorial acquisitiveness, and purist conceptions of race. (1991, p. 1386.)

\subsection{Accent and stereotypes}

While theorists such as Lippi-Green and Matsuda have looked broadly for evidence of accent discrimination at a societal level, decades of laboratory experiments also provide ample evidence that stereotypes do indeed exist on the individual level.

The idea that people may associate personality characteristics with specific speech patterns has been considered in a wide range of studies around the world over decades in fact, this may be the most widely researched area of accent discrimination. The first such documented study appears to have been in 1931, when BBC audiences in Britain were invited to provide personality profiles of certain voices heard on the radio (Eisenhower, 2002). While researchers quickly realised that there was very little correlation between voice and personality, the idea that accent could change a listener's perception of a message nevertheless resulted in a proliferation of studies on stereotype formation and accent (Eisenhower, 2002; Munro, 2003). 
Underlying much of this research is assumed characteristics theory, referred to in various research since the 1960s (Gill, 1991, p. 21). Under this theory, individuals perceive those who are part of an 'in-group' to have more favourable characteristics than those 'on the outside.' Accents that are 'different,' therefore, result in negative stereotypes and the desire to exclude. Similarily, J. Berger's status characteristics theory originally described in 1970 (Simpson \& Walker, 2002) states that certain characteristics, including accent, may be used by listeners to determine social status. Under this scenario, accent can affect a listener's evaluation of a speaker's performance at various tasks, or can lead to a listener accepting or rejecting the influence of the speaker due to presumed social status (Riches \& Foddy, 1989). Inherent in both these theories is the idea that a speaker's traits will elicit reactions based on stereotypes beyond what can be observed by their behaviour.

A significant number of laboratory experiments have documented the extent to which listeners make stereotyped assumptions about characteristics of accented speakers. While many compare native-spoken varieties of an accent (e.g. African American Vernacular English and North American English), we will focus here on studies that have looked at foreign-accented speakers.

In most examples, studies are conducted using a verbal match-guise technique under which a bilingual native speaker is recorded speaking with a standard accent (normally American English with a mid-western, 'news anchor' accent) and then is recorded again uttering the same words or phrases but in a foreign accented variety of the same 
language. Native speaker subjects then listen to both recordings and are asked to evaluate the two 'different' voices to determine if they can extrapolate personality characteristics of the speaker. For example, listeners may be asked to rate how attractive or how intelligent they think the speaker is. Results are then compared to determine if the speaker receives more favourable ratings when speaking with a foreign accent or a 'standard' one.

Not surprisingly, these studies for the most part have revealed that foreign-accented speakers receive lower ratings on measures such as intelligence and ability than standardaccented speakers, though some studies have indicated that foreign-accented speakers may be viewed more positively on social characteristics such as friendliness and likeability (e.g. Riches \& Fody, 1989; Lindemann, 2005). An overview of just some of these studies demonstrates that native English speaking laboratory listeners may negatively evaluate Greek-accented speakers (Riches and Foddy, 1989), as well as Malaysian accents (Gill, 1994), Mexican Spanish accents (Spicher, 1992; Giles et al., 1995), Japanese accents (Cargile \& Giles, 1998), and Korean accents (Lindemann, 2003).

At the same time, studies indicate that certain groups may face less stigmatisation by listeners, or may even be rated more favourably than 'standard' speakers. For example, Delamere (1986) found that laboratory listeners rated French and Malay speakers as even more intelligent, better leaders, and more prestigious when their accents were also coupled with a degree of language error. Along similar lines, Lindemann (2005) asked students to rank countries based on how correct, friendly, pleasant and familiar the 
accents of ESL speakers were from those countries. She found that non-stigmatised groups such as French and Germans were rated more highly than stigmatised groups such as Latinos and Asians. A study by Kalin, Rayko and Love (as cited in Rubin et al., 1991) also found that Canadian listeners perceived German-accented speakers as more suitable for high-level employment than speakers with South Asian or West Indian accents. This is evidence that accent discrimination is not a stand-alone phenomenon, but rather is linked to broader issues of racialisation and other types of prejudice. While match-guise studies proliferate, further analysis clearly remains to be done on the intersection of accent with race, gender, and other forms of discrimination and stereotype formation.

It is also interesting to note that studies indicate that urban listeners may be more tolerant of accents, and that university listeners may express frustration with accented speakers (e.g. studies of reactions to accented teaching assistants and professors such as Gill, 1991), but do not necessarily make the leap to associating accents with personality traits (Munro, 2003, p. 39).

\subsection{Accent and perception of language ability}

While laboratory studies have largely looked at accent and its effect on stereotypes about personality characteristics, a much smaller number have looked at accent and perceptions of actual language ability. This area is of particular importance to our study of accent as an arbitrary barrier to immigrant labour market integration because while most individuals today would easily agree that linking personality characteristics to a person's 
accent is discriminatory, the lack of causal link between accent and language ability is less understood.

Pioneering work has been undertaken on this topic by Tracey Derwing and Murray Munro, who conducted two studies in 1995 and 1997 in which they examined the relationship between accent, perceived comprehensibility, and actual intelligibility. Both of these studies found that there is not a strong correlation between accentedness and intelligibility. There is, however, a stronger relationship between accent and perceived comprehensibility. That is to say, listeners who rate foreign-accented speakers as having strong accents are likely to give those same speakers a low score on a comprehensibility rating, though the perceived strength of accent did not necessarily reduce the ability of the listeners to accurately transcribe or understand the accented speakers' utterances.

The reality that personal bias may cause a listener to dismiss or deny the comprehensibility of an accented speaker, regardless of how much they actually understand, highlights the importance of sensitising listeners to the notion of accent. Derwing (2003) in particular discusses the notion of a 'communicative burden,' arguing that while communication is a two-way street, native speakers often feel justified in dropping their half of the burden when they hear a foreign accent. Matsuda echoes a similar sentiment when she argues that there is no reason for accent to impede communication when "listeners are motivated and non-prejudiced" (1991, p. 1367), as "comprehension is as much a function of attitude as it is of variability" (op. cit., p. 1328). 
Derwing and Munro's 1997 research did also observe a correlation between familiarity with an accent and intelligibility scores, agreeing with Gass and Varonis' 1984 conclusions on the same issue. The extent to which native speakers can be specifically trained to improve their perceptions of foreign accents, however, is unclear. A study on this topic by Jongman et al. (2003) found that training failed to improve listeners' perceptions of Spanish-accented words, and Derwing and Munro (2002) also found that linguistic training did not improve listeners' comprehension of Vietnamese-accented speakers, although it did increase the listener's empathy with the speaker.

While it is recognised that accented speech may take longer for a listener to process, particularly when that accent is unfamiliar (Derwing \& Munro, 1997), this research nevertheless demonstrates that perceptions of accent do not necessarily correlate with actual comprehension.

\subsection{Accent discrimination and the law}

A significant criticism of the laboratory studies referred to in the previous two sections is that they are far removed from the real, everyday experiences of accented speakers. Finding evidence that listeners in laboratory environments do indeed form stereotypes based on the accents of speakers, and may even make judgements as to speakers' language ability based on those stereotypes or perceptions of accent, does little to elucidate either the real world discrimination that results from such stereotypes or the effects of such discrimination. 
For such concrete examples of accent discrimination, we may turn to two authors who have researched court cases documenting the effects of accent discrimination: Mari Matsuda in the United States and Murray Munro in Canada.

\subsubsection{Accent discrimination cases in the US}

Mari Matsuda's seminal, oft-quoted 1991 article "Voices of America" gives an account of US jurisprudence on accent discrimination and various attempts to use Title VII of the Civil Rights Act to seek redress. The cases described provide thought-provoking examples of difficulties faced by accented speakers in the American labour market. In one example, Matsuda describes the case of a Filipino man judged to be fluent in English but denied a job as a clerk at a local drivers licensing office for fear clients may not understand or may become agitated by his accent. In another case, a Hawaiian-accented meteorologist who is an English native speaker is not given a job as a weather announcer in Hawaii, though qualified, because of a perceived desire by audience members to hear someone with a 'standard' American accent.

While Title VII includes a ban on discrimination in hiring on the basis of national origin, in these and other cases described, no Title VII discrimination was found to have taken place. Instead, US judges continued to uphold the right of employers to consider accent a valid criterion for hiring. As described by Matsuda, "in every accent case the employer will raise the "can't understand" defense, and in almost every reported case, the courts have accepted it" (1991, p. 1348). 
Arguing that American judges need to move beyond their myopic focus on "black-white" issues in discrimination cases (Cameron, 1997) and begin to recognise the full breadth of discrimination, including on the basis of accent, Matsuda advocates that courts should "state unequivocally that once a person's speech is found functional, the employer may not reject it because a competitor's speech is "less foreign." (1991, p. 1386). In fact, she develops for law makers four basic questions against which accent cases should be evaluated: what level of oral communication is actually required for the job; did the employer evaluate the candidate's speech fairly; is the candidate intelligible to "relevant, non-prejudiced listeners," and; what accommodations could reasonably be made given the job and any limits on intelligibility (op. cit., p. 1368).

\subsubsection{Accent discrimination cases in Canada}

Were Matsuda to undertake an analysis of Canadian court and tribunal rulings, she would likely find them to be more in keeping with her ideal of requiring employers to accept accented speech so long as it is functional. Murray Munro, however, argues that Canadian courts still have further to go.

In his 2003 article "A Primer on Accent Discrimination in the Canadian Context," Munro identifies three types of accent discrimination cases that have arisen in the Canadian justice system: cases where a particular accent has been considered a job requirement (explicitly or implicitly); where accent has been used to stereotype, and; where accent has played a part in workplace harassment. 
Munro's examples where accent has been considered a job requirement include the case of a substitute teacher originally from Poland who spoke fluent though accented English. After working successfully for some time, he stopped receiving calls for work when an administrative staffer placed a note on his file that he "did not speak English." When he became aware of the note and asked that it be removed, he once again began to receive offers of work. In this case, British Columbia's Human Rights Commission upheld his complaint and awarded the teacher damages for lost wages, hurt, indignity and embarrassment (Munro, 2003, p. 44).

In a similar type of case, a French-accented speaker working at a travel agency in Victoria, British Columbia, was fired because clients had indicated they had difficulty understanding him. In this case the claim was dismissed, due in part to the fact the agency had other French-accented employees on staff for whom accent was not considered a problem, supporting the assertion that the claimant's accent was unusually difficult to understand. In another example, a clerical worker at a trucking company challenged his dismissal, claiming it was due to discrimination against his accent. As with the Frenchaccented travel agent, this dismissal was upheld as the employer successfully demonstrated that language issues went beyond accent and that the individual had confused orders from customers.

Key to decisions in these cases is court and tribunal evaluation of the notion of Bona Fide Occupational Requirements, or BFOR. Where employers could not demonstrate that accent was inhibiting an employee's ability to function in a job, dismissal was not 
justified. Where employers could successfully argue that accent was a direct cause or contributing factor in an employee's irability to carry out real job requirements, however, judges and tribunal members ruled in the employer's favour. Munro summarises this approach as affirming that "denying someone employment on a protected ground is not discrimination if there is a legitimate reason to require some type of knowledge or skill of an individual" (2003, p. 43). While this response is clearly more enlightened than that taken by US courts, Munro remains critical of the level of impartiality in many of the decisions. Canadian courts and tribunals may use objective criteria to determine whether BFOR exists, but speaker proficiency is still often determined subjectively rather than through the use of expert witnesses or standardised test scores such as the Test of Spoken English (op. cit., p. 45).

As mentioned, Munro also looked at cases where accent was used to justify stereotypes, such as a woman of Cree background being denied an apartment in Saskatchewan while a 'standard' accented friend who called later was told it was still available. A number of cases were also cited under which individuals claimed harassment on the basis of their accent, such as a guard at a jail being the target of racist comments including having his accent mimicked by another employee, and a Yugoslavian immigrant who had lived in Canada since age 17 but frequently received negative comments from her employer about having "broken English." In all of these cases, claimants were successful.

These cases, in both the US and Canada, provide clear evidence that accent discrimination does indeed take place and may have negative implications for accented 
immigrants seeking work. The Canadian justice system may be taking a more progressive approach by penalising employers whose discrimination is brought to its attention; however, as argued by Munro, even Canadian courts remain tentative in recognising the divide between language ability and accent. True legal protection against accent discrimination requires the recognition that accent is a permanent part of a person's identity, not just a learnable skill such as vocabulary or grammar use. Arguing for a reframing of how courts protect accented speakers, Matsuda states the following:

The way we talk, whether it is a life choice or an immutable characteristic, is akin to other attributes of the self that the law protects. In privacy law, due process law, protection against cruel and unusual punishment, and freedom from inquisition, we say the state cannot intrude upon the core of you, cannot take away your sacred places of the self. A citizen's accent, I would argue, resides in one of those places. (1991, pp. 1391-1392.)

\subsection{Summarv: accent and discrimination}

While everyone has an accent, various institutions are criticised for perpetuating a 'myth' of standard language use in North America, including a standard accent. This myth has been shown to exist in the reactions of individuals to accented speakers, with match-guise studies demonstrating the extent to which pronunciation can elicit stereotypes. Yet accent does not need to affect communication when the listener is willing. Studies by Derwing and Munro reveal that perceptions of the 'heaviness' of an accent are not directly related to how much of a person's speech is actually understood. Outside of the laboratory, numerous cases of accent discrimination have been documented in Canada and the US, 
and while Canadian human rights law appears to provide more protection for accented speakers than American anti-discrimination legislation, work nevertheless remains to be done on removing subjectivity from how courts separate accent from language ability. Links between accent discrimination and racialisation are evidenced by the attribution of positive characteristics to individuals with high status accents, and the consistency with which legal cases on accent discrimination focus on already racialised groups. 


\section{ACCENT AND THE LABOUR MARKET}

Discrimination in hiring practices may take many forms. Jeffery Reitz (1999) has estimated that between $15-30 \%$ of the earnings differential between immigrants and the native-born may be due to racialisation (p. 16). How much of this differential stems from inappropriate assessment of language ability through accent, however, is unknown, as very little research exists on employers' impressions of accent, or how accent plays a part in their evaluation of potential employees.

As noted in the previous section, there are certainly many documented cases of accent discrimination in the workplace. In a 1986 study on the integration of Black Africa immigrants in Toronto, as many as $60 \%$ of subjects felt their accents were unfavourable in terms of "integrating into society and finding employment" (Kasozi, p. 10). A similar article looking at the experiences of African women in British Columbia uncovered significant experiences with accent discrimination, such as women being told that their accents were "incomprehensible" during job interviews, or frequently having their pronunciation "corrected" (Creese \& Kambere, 2003). Such corrections were particularly offensive where interviewees spoke English as a first language, and saw their accents as integral to their African-Canadian identity.

Employers for their part are in some cases surprisingly willing to acknowledge discriminatory behaviour towards accented job candidates. In one of the few broad studies that appears to be available including questions on accent discrimination, $10 \%$ of a sample of 461,000 American companies employing millions of individuals "openly if 
naively admit that they discriminate on the basis of a person's foreign appearance or accent" (Lippi-Green, 1994, p. 74). Anecdotal evidence cited by Lippi-Green also indicates that job agencies, specifically noted in New York City, have openly publicised "no accent" as a job requirement (op. cit., p. 24).

In the Canadian context, the PPF study referred to in section 2 (Lopes, 2004) looked at barriers to hiring immigrants identified by Canadian employers. Of survey respondents, $18 \%$ said that immigrants were very likely to experience language difficulties, and $14 \%$ said immigrants were very likely to experience communication difficulties (p. 6). When asked to elaborate on what they considered language skills, focus group participants included in their descriptions "difficulty understanding immigrants because of their accents" (idem.).

But the question remains: to what extent are employers confounding accent and language ability, perhaps setting valid job requirements for communication skills but inappropriately evaluating immigrant candidates on the basis of their accents rather than using objective measures? To what extent do employers discriminate when they evaluate?

To look at this question, a small sample of Ottawa employers were asked about how they would judge the language ability of immigrant applicants for a range of different jobs. This study is discussed below. 


\subsection{Research methods}

With a working hypothesis that employers inappropriately use accent to evaluate immigrant job candidates' language ability, a survey was developed for employers asking a variety of questions about how the language ability of nonnative English speaking immigrants (NNEIs) is evaluated in the hiring process (see Appendix 1). This survey sought not to determine whether employers actually discriminate against accented immigrant job candidates, something that would be very hard to establish without an indepth evaluation of hiring practices and obtaining company permission to observe real interviews with candidates whose language ability had been independently evaluated. Instead, the survey attempted to evaluate the extent to which employers openly acknowledge that accent is considered when a candidate's language ability is being assessed. Under scrutiny were employer attitudes rather than actions.

The initial survey was pilot-tested on four individuals who participate in hiring decisions at their respective organisations to ensure clarity and neutrality of tone. The questionnaire was then modified based on their suggestions.

A sample of employers was chosen by selecting five days of job ads from a major Canadian online job website, with oral consent from a website representative. To limit the study size and to facilitate the delivery of surveys, jobs were filtered to include only postings in the Ottawa area (Ontario only). Ottawa is the fourth largest city in Canada, and with immigrants making up $17.6 \%$ of the population it has a similar proportion of immigrants to the national average (18.4\%). 
Job postings were also filtered to include only private sector employers. While the public sector is a significant employer in Ottawa, highly regulated screening and hiring practices would require a separate study to evaluate accent discrimination in government hiring. Postings at non-governmental and not-for-profit organisations were also screened out due to concerns that differences in organisational culture with the private sector might also call for separate study. Finally, postings explicitly requiring bilingual applicants (i.e. English and French) were screened out due to concerns that survey questions may not be as clear if respondents were considering ability in two separate languages.

The final sample included 67 job postings. Jobs covered a wide variety of sectors, from high-tech companies (the second largest employer in Ottawa after the federal government) to retail businesses to an auto parts wholesaler to a lumberyard. Positions also ranged in responsibility from administrative staff to vice president.

Surveys were hand delivered over a five day period. A cover letter was included with each survey explaining the research project and asking employers to fill out the survey with the particular job posting in mind (see Appendix 2). Also attached was a consent information sheet (Appendix 3) and a self-addressed, stamped envelope in which to return the survey. In many cases surveys were handed directly to the decision maker for the particular job, though for larger companies the survey often had to be left with administrative staff for later delivery to human resources (HR) departments. As an 
interesting aside, only one survey recipient appeared to be an NNEI, the vast majority of those accepting surveys being Caucasian Anglophones.

Returned surveys were anonymous, containing no individually identifying company information. Although it was hoped that hand delivering surveys would result in a higher return rate than the $10 \%$ average for questionnaires sent out by mail (Newman, 2006), unfortunately only eight surveys were returned. This represents a response rate of just under $12 \%$. A follow-up email was sent to survey recipients for whom personal contact information existed (e.g. it was part of the original job posting) resulting in one additional response, for a total of nine ( $13 \%$ response rate). Due to time and financial constraints, no further responses were sought. While a sample size of nine is far from ideal, this study nevertheless revealed some interesting preliminary results and potential areas for future study.

\section{$\underline{5.2 \text { Survev results }}$}

\subsubsection{Job and respondent characteristics}

The nine surveys returned came from companies ranging in size from fewer than 25 to over 500 employees. Position types were also diverse, from retail sales at a salary of less than $\$ 30,000$ a year to a software developer at an annual salary of $\$ 50-60,000$ to a management position earning over $\$ 70,000$ a year. All but one respondent estimated that their company had at least "a few" employees who were immigrants and did not speak English as a first language, with two indicating this group made up "a lot but less than 
half' of the company and one company (with 100-500 employees) indicating they made up "more than half."

Five respondents were female and four male. Five were between the ages of 21-30, one respondent was 31-40, and three were 41-50. Survey instructions asked that respondents either be making the final hiring decision or be one of the decision makers if a candidate was being assessed by multiple people. Two thirds, six of the nine, were in human resource units of their respective organisations (e.g. as an HR specialist or recruiter). Only two respondents (both managers) specifically indicated non-HR job titles.

Interestingly, none of the nine respondents revealed an ability in any language other than English or French. Six spoke English as a first language, two French, and one indicated she was fluently bilingual. Seven of the nine also spoke a second official language while two stated they were monolingual Anglophones.

All but two respondents indicated they had previously hired NNEIs, both 21-30 year olds in HR units of a medium or large company (100-500 and 500+ employees). Most had hired NNEIs into a wide variety of positions, including economist, accountant, and programmer. One indicated hiring NNEIs only for lower-skilled retail positions, though the respondent was a manager currently hiring for a retail position, indicating he may not be a decision maker for higher-skilled positions. 
Respondents were also asked if they had any special training evaluating language ability as this training would likely colour their responses. Only one respondent indicated they had such training, though no details were given in the space provided.

\subsubsection{Declared methods of evaluation and attitudes towards language}

When asked how language would be used for the position in question, all respondents indicated it would be necessary to talk casually with colleagues either often (eight respondents) or sometimes (one respondent) (see table 1). All but two positions also required talking with clients casually, and the same number required writing emails. Fewer positions, five, required frequently meeting formally with clients (three never required formal client meetings) or reading complex documents (four indicated sometimes). Only four positions often required writing formal reports (four indicated sometimes and one never). Individual respondents also added that English would be needed for "preparing customs documents"; “dealing with American customers";

Table 1: Language use in position

\begin{tabular}{|c|c|c|c|c|}
\hline H(1) & $y^{3}$ & somerfines & 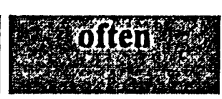 & 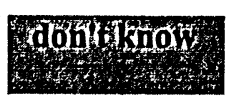 \\
\hline sualify & & & 8 & \\
\hline tatking with clients casually &  & Whan & 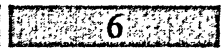 & 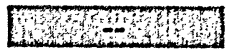 \\
\hline meeting formally with clients & 3 & 7. & W 5 & Mrin \\
\hline writing email & 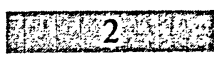 &  & 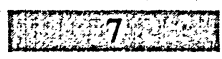 & [FE \\
\hline Writing formal reports & 1 & HX & Wh 4 का & W \\
\hline reading emoils & 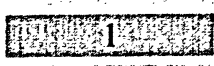 & W1 & W7Th & W \\
\hline reading complex documents & -7w & 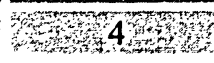 & Whon 5 & Why \\
\hline preparing customs documents & Finn & W & 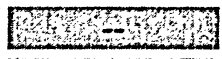 & 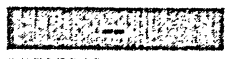 \\
\hline Tdealing with American customers & - & 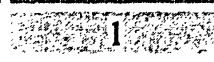 & Wentwan & When \\
\hline W making presentations : & Wh- & 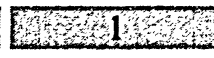 & W-D & Dan-m \\
\hline Fattending conferences & $-\cdots$ & & & \\
\hline
\end{tabular}


"making presentations" and; "attending conferences".

Seven of the nine respondents indicated that ability in another language would be useful for the position, with four of the seven mentioning French specifically. Six specified that additional languages would be useful for communicating with clients and customers.

When asked about how the language ability of NNEI job candidates would be evaluated, the highest ranked method was through grammar usage during an interview (six respondents indicated this method would be important or very important) (see table 2).

Five respondents indicated that a written test or evaluation of English in a résumé was an important or very important method of determining language ability. Strength of accent in an interview was rated the fourth most important evaluation method (three respondents

Table 2: Methods of evaluation

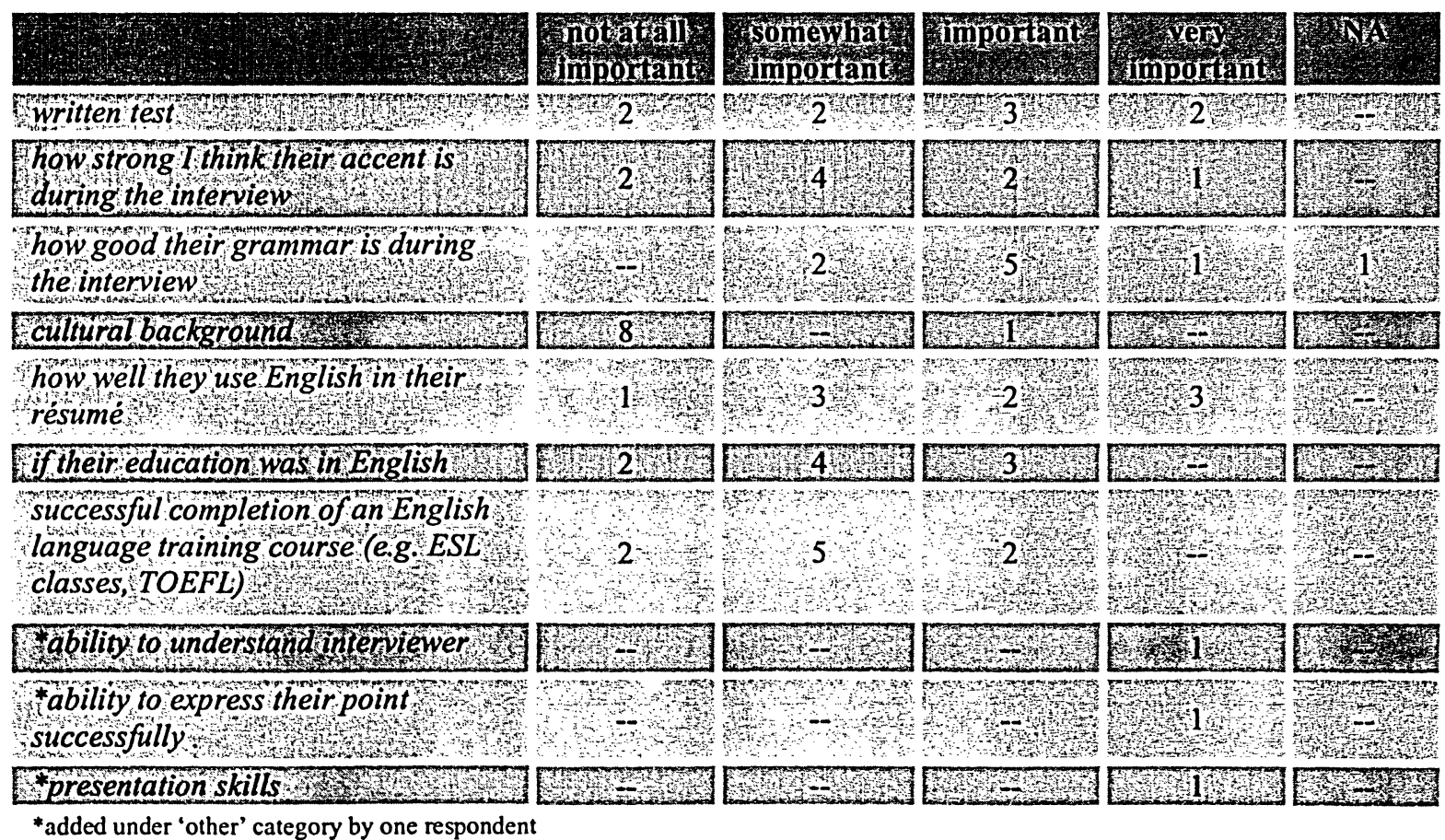


indicated it was important or very important), followed by whether the candidate's education was in English (three stated this was important) or whether the candidate had completed an English language training class (two said this was important).

Only one respondent indicated that evaluation of language ability would include the person's cultural background, with the remaining eight stating that this was not at all important. The one respondent who said that this was important rated almost all other evaluation methods as 'very important' and added two additional methods, perhaps as the position was in management and therefore candidates were expected to demonstrate strongly a wide variety of skills. This respondent's inclusion of cultural background as an important evaluation method could be an indication of possible discrimination, or, given the nature of the job, may have resulted from a misinterpretation of the question to refer to evaluating the applicant fit within organisational culture.

One respondent also indicated they would evaluate NNEI candidates based on their ability to understand an interviewer or express their point successfully, and another included an evaluation of the person's presentation skills.

In the next survey section, respondents were asked what type of language training they felt would be most useful to prepare an NNEI for the position in question (see table 3). All respondents agreed that it was either important or very important that relevant language training focus on grammar and vocabulary. No respondents agreed that it was important that training focus on helping NNEIs try to "sound more Canadian," a positive 
result for a question that was designed to detect respondents with more extreme views on immigrant integration. While eight respondents felt it was important or very important for relevant training to focus on speaking comfortably and seven on writing, only one felt it was important for training to focus on accent. Five respondents did feel a focus on accent was "somewhat" important for their positions. Of these five, all had indicated that the evaluation of accent in the interview process would be somewhat to very important in evaluating the language ability of NNEI candidates.

In the final section of the survey, respondents were asked the extent to which they agreed or disagreed with a series of statements related to language and their advertised position (see table 4). All respondents either agreed or strongly agreed that they would consider hiring someone even if they had a "strong foreign accent," a very positive result. While all respondents indicated they disagreed with the statement that they would only hire someone for the position whose first language was "standard English," only four strongly disagreed while the rest disagreed, indicating a certain reticence in the extent to which they would admit to being comfortable hiring NNEIs. The four who strongly disagreed

Table 3: Perceived useful language training components

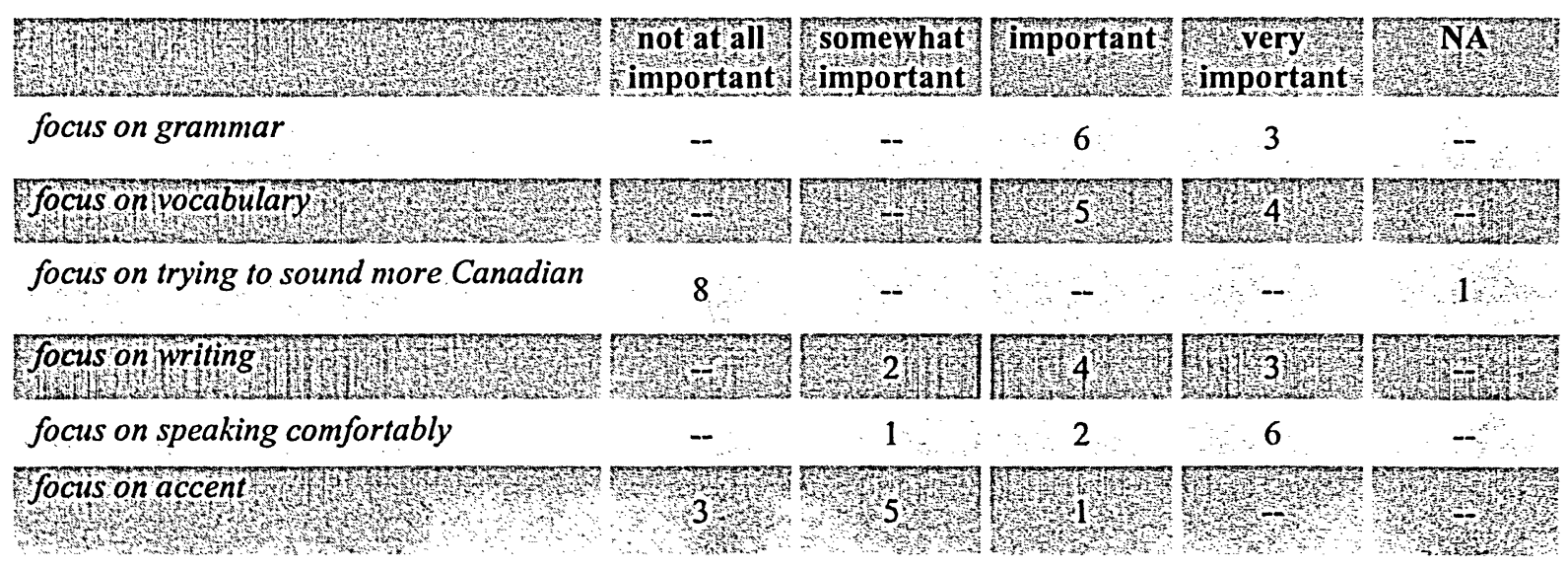


with this idea had no particular similar characteristics or responses to other questions: one had previously indicated a concern with cultural background, and responses on the importance of accent when evaluating language at an interview ranged from not at all to very important.

Two respondents indicated that they would not hire someone whose accent "made them difficult to understand" even if they could write well in English. Both of these positions were rated as requiring frequent oral communication with colleagues and clients. The two respondents both also indicated that accent would be an important indicator of language ability during interviewing and that appropriate language training should focus on speaking comfortably.

Table 4: Agreement with statements

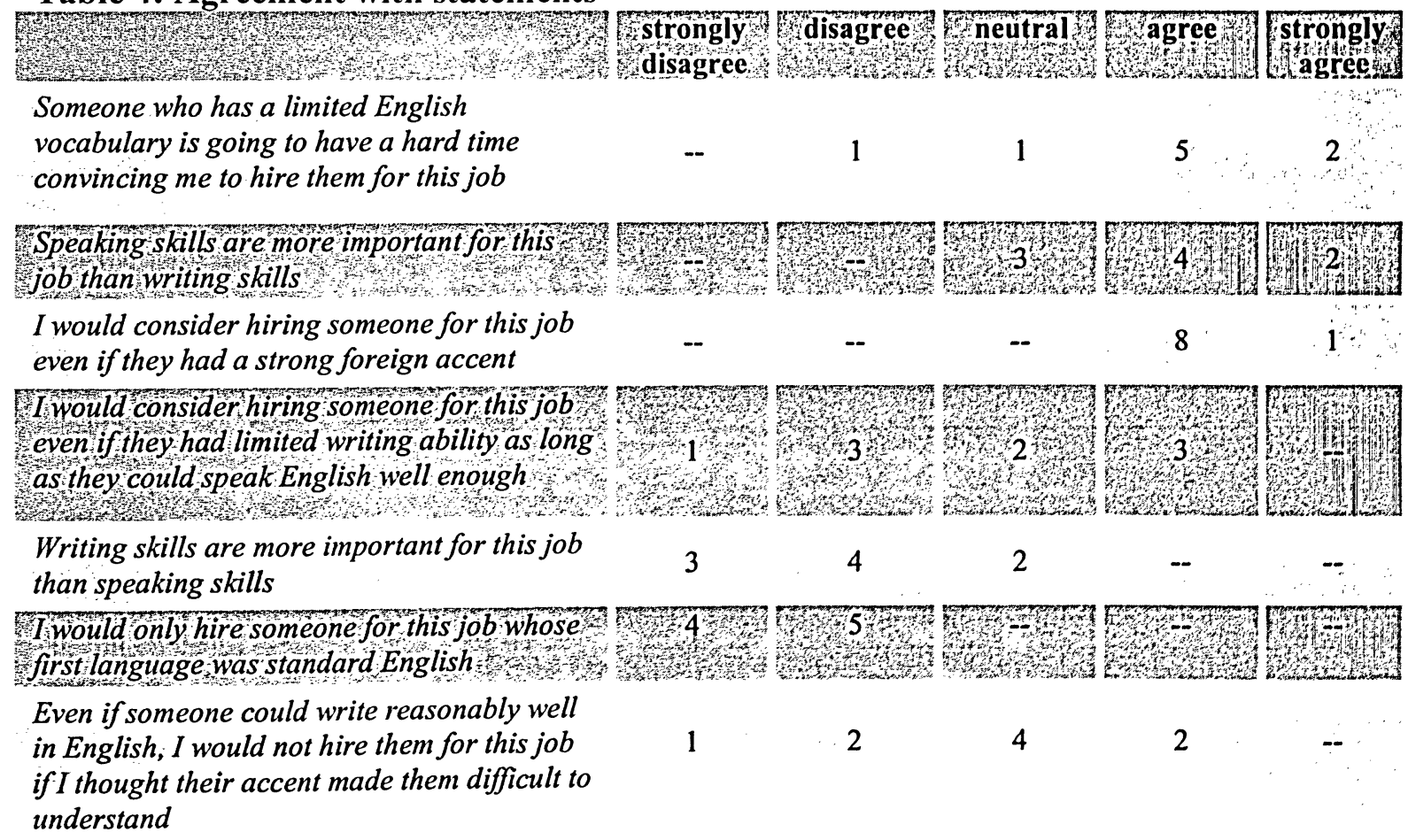


To determine the strength of the correlation between respondents' concern with applicant accent and the self-declared importance of oral language use in a given position, two measures were created. The first compiled responses to four questions looking at oral language skills needed for the job in question. A score of 1 on this measure would indicate no concern with oral skills, while a score of 5 would indicate the maximum concern with oral skills.

Similarly, three questions looking at the importance respondents placed on accent were compiled. A score of 1 on this measure would indicate no concern with accent, and a score of 5 would indicate the maximum concern.

As can be seen in chart 1 , no strong correlation was found between these two measures.

While concern with accent fluctuated little, from a low of 3 to a high of 4 , the importance of oral language use fluctuated more significantly, from as low as 2 to as high as 4.25 . Respondents who highly rated a position's need for oral language did not necessarily have a high concern with accent, nor was there a particularly low concern with accent for positions with a low declared need for oral language.

\section{Chart 1.}

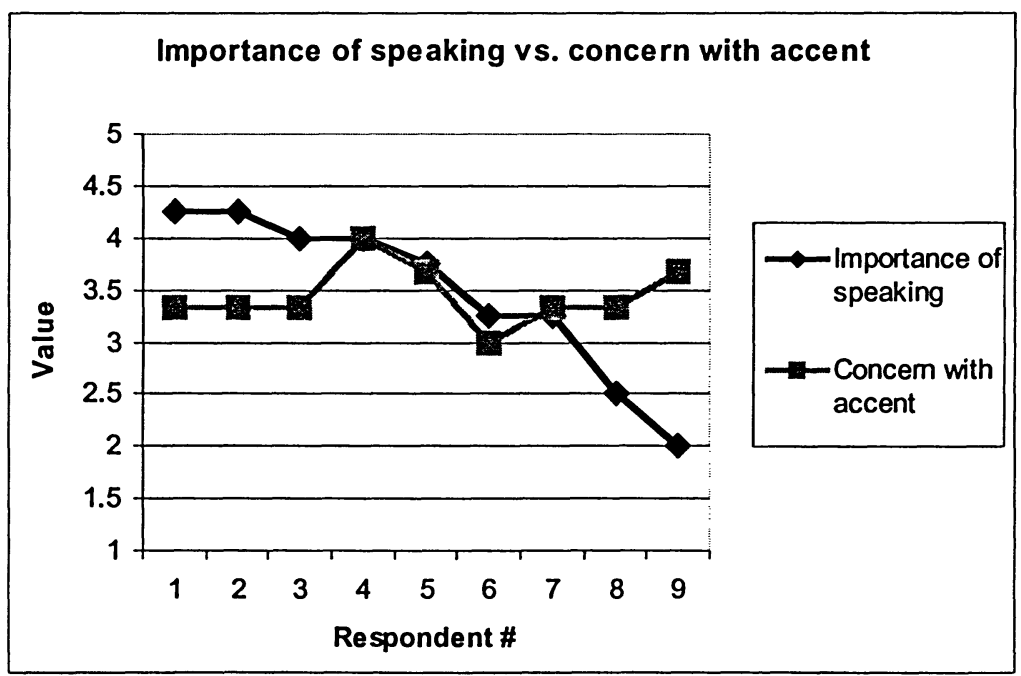


The one revealing characteristic of three respondents with the highest concern with accent (respondents 4, 5, and 9), was their age. These three were also the oldest respondents, all between the ages 41-50. They were also the only three to rank vocabulary as a very important aspect of relevant language training, all others ranking vocabulary as less important.

\subsubsection{Discussion of results}

A majority of respondents to the survey admitted that they believed it was appropriate to use accent to evaluate the language ability of nonnative English speaking immigrants. A majority also believed that it was important or somewhat important for relevant language training classes to focus on accent, and not all were strongly convinced that they would hire someone for the position in question whose first language was not English. These results could not simply be explained away by a corresponding concern with oral language use for the position in question. The most salient factor resulting in a high concern with accent, in fact, was age of the respondent. In general, some employers displayed what could be a lack of knowledge about accent and reasonable expectations for accented speakers - an ignorance in attitudes that could lead to discrimination in actions.

At the same time, respondents' views were far from extreme. Almost all respondents agreed that cultural background was not a valid marker of language ability and that relevant language training need not seek as a goal helping students to "sound more 
Canadian." This was a positive finding. While self-declared attitudes on accent do not necessarily correlate to action when hiring, employers nevertheless appeared to show some, if not perfect, awareness of appropriate ways to respond to more overt questions on accent discrimination.

As previously discussed, one interesting respondent characteristic was a consistent lack of ability in languages other than English or French. While immigrants make up $17.6 \%$ of the population of Ottawa and all but one respondent indicated there were NNEIs working for their organisation, this group may have difficulty penetrating human resource and/ or management areas where personnel decisions are being made. If indicative of a wider trend, this result could have broad implications as labour market gatekeepers remain unrepresentative of the broader population.

One reason for this finding, however, may be the nature of the Ottawa labour market. While Ottawa's immigrant population is proportionally close to the national average, the bilingual nature of many of its workplaces may result in HR positions being purposely staffed with bilingual individuals (seven of the nine survey respondents). This hypothesis of course assumes higher levels of official language bilingualism amongst the Canadian born than immigrants. Nevertheless, the relative uniqueness of bilingualism in Ottawa (similar if not comparable to only a few cities in Canada such as perhaps Montreal or Moncton) would have to be taken into consideration if a future study were conducted in multiple cities. 
It is also important to point out that a bilingual individual making hiring decisions may react differently to questions about accent than someone who is unilingual, given their experience communicating in a second language. This would not necessarily result in a more open hiring environment for immigrants, but rather a heightened awareness of the 'right' way to answer questions about accent. This hypothesis was not born out in this particular study as neither native French speakers (responding to the survey in their second language) nor bilinguals answered questions consistently with each other, though a larger sample could have revealed more similarities in certain attitudes.

Finally, an important consideration was the high proportion of respondents working in HR units (six of the nine), as HR specialists are likely to bring different attitudes to the hiring process than managers or non-HR specialists. Companies that are large enough to have HR specialists may have more formal hiring procedures which attempt to limit (at least overt) discrimination compared to many smaller companies. Individuals with HR expertise are also likely to be more conscious of how they respond to questions about their evaluation methods compared to non-specialists who may be more willing to admit to relying on intuition when determining competencies.

\subsection{Survev conclusions}

While not extreme in their views, many employers nevertheless revealed a readiness to rely on accent as a factor in determining an applicant's proficiency in English. This readiness indicates a lack of knowledge amongst the employers surveyed about the nature 
of accent and its relevance as a marker of language ability. Attitudes towards accent may be less problematic for younger decision-makers.

Future research on this topic would benefit from a larger sample size and, if resources permit, a wider sample area encompassing more than one city. Hand delivery of surveys may not result in a significantly higher return rate than a mail-out. When analysing results, city demographics and labour market characteristics need to be taken into consideration. 


\section{CONCLUSION AND RECOMMENDATIONS}

Adult learners of a second language will always have an accent. This accent is a marker of a speaker's linguistic history, evidence of bilingualism or even multilingualism. Accented speakers should be able to take pride in their speech, revealing as it does multiple layers of language learning and linguistic ability.

But rather than recognise a foreign accent as a badge of honour, many native speakers perceive differences in speech patterns as a defect or inadequacy. While likely less linguistically agile and unable to speak the first language of the person with whom they are communicating, listeners may nevertheless expect a speaker not only to convey their message, but also strive to sound just like them.

In 2006, Canada accepted 251,649 immigrants from over 200 countries around the world. $87 \%$, the vast majority of newcomers, did not speak English or French as a first language (Citizenship and Immigration, 2006a). The 2006 Annual Report to Parliament on Immigration (Citizenship and Immigration, 2006b) stated that (amongst other reasons) these immigrants were admitted because "Canada is facing skills shortages at home" (p. 3). Unable to meet our own labour market needs, Canada has turned to the global market for the skill and talent demanded by our economy. But for immigrants to be able to succeed in the labour market to their maximum potential, they must be evaluated on their real abilities, not have their skills filtered through arbitrary barriers such as accent. 
Based on the results of research conducted for this paper, policy makers and those who work with accented immigrants may wish to consider the following recommendations:

\section{Employers need information about what accent is and resources on} appropriate ways to evaluate language ability. Recent government funding to employer-focused initiatives, such as the Toronto Regional Immigrant Employment Council (TRIEC), demonstrates a recognition by policy makers and the private sector that cooperation is needed to improve immigrants' success in the labour market. As well as incentives to hire immigrants, however, employers need information about flaws in current hiring practices. Accent is often misunderstood by employers who may use it to judge a candidate's language ability or who may not recognise it as a permanent marker of difference. Government strategies to engage employers in hiring immigrants should include sensitising those making hiring decisions to accent, and providing information on appropriate (and inappropriate) methods of evaluating the language ability of immigrant applicants.

2. ESL classrooms need to address accent discrimination with students. Whether or not an adult ESL class includes a component on pronunciation, teachers should work with students to ensure they have reasonable expectations about adopting a new phonology. Students should also be encouraged to view their accents as natural and even a positive marker of linguistic accomplishment, and should be empowered to face the accent discrimination that they are likely to encounter outside of the classroom environment. 


\section{Accent discrimination needs to be recognised in anti-discrimination and}

diversity initiatives. Too often in discussions on racism and prejudice, accent is not included as a characteristic for which discrimination may take place. That it is little understood may exacerbate accent being overlooked, but continuing to disregard it leaves misconceptions unchallenged. Policy makers and public educators in particular need to ensure that programming for anti-racism initiatives confronts accent discrimination along with other forms of prejudice.

English has become a global lingua franca. Today, people from around the world communicate with each other in English, though it may be a second or even third or fourth language for those taking part in the conversation. In fact, foreign-accented English may soon become the most common language in the world (Jongman et al., 2003). Native English speakers enter this international dialogue with a significant advantage: they are not expected to communicate in a language other than their mother tongue. Setting up standards of correctness which are unnecessary for communication does nothing but serve to maintain this accidental place of global linguistic privilege.

Accent discrimination is not a unique form of stigmatisation. It is part of a multifaceted and interconnected web of prejudice that includes race, gender, sexuality, and many other notions of identity, whether chosen or imposed. A male, heterosexual, Caucasian nonnative speaker from a developed country is unlikely to face barriers due to his accent to the same extent, or at all, when compared with someone who has been gendered, racialised, sexualised, and who is from the global South. 
Discrimination and privilege on the basis of accent exists in Canada. If we truly seek to recognise and rectify exclusion within our borders, we must do a better job of hearing audible minorities. 


\section{SURVEY ON IMMIGRANT NONNATIVE ENGLISH SPEAKING JOB CANDIDATES}

Please ensure that this survey is filled out by the person who is responsible for making the hiring decision for this position. If multiple people are responsible for this decision, please provide details about your role in the hiring process (e.g. if you are a member of the hiring committee):

If you would like to qualify any of your answers, feel free to write comments anywhere on the survey.

Please check one for each of the following:

\section{INFORMATION ABOUT YOU}

1. Gender:

|_Male $\mid$ _Female $\mid$

2. Age:

$\mid \_$Under $21\left|\_21-30\right| \_31-40\left|\_41-50\right| \_$Over $50 \mid$

3. Your job title in the organisation:

\section{ORGANISATION}

4. How many people work at your organisation? (If your organisation has more than one location, please provide an estimate of the total number of employees for the entire organisation)
$\mid \ldots$ Under $5 \mid$
$5-25 \mid$
25-100|
$100-500 \mid$
_Over 500 |

5. How many immigrants do you think work at your organisation for whom English is NOT a first language. (If you are not sure, please estimate.)

|_None $\mid$ _ A few $\mid \_$A lot but less than half $\mid \_$More than half $\mid \_$Almost all $\mid$_All $\mid$

\section{POSITION}

6. What is the yearly salary for the advertised position?
$\mid$ _Less than $\$ 30 \mathrm{k}\left|\_30 \mathrm{k}-40 \mathrm{k}\right| \_41 \mathrm{k}-50 \mathrm{k}\left|\_51 \mathrm{k}-60 \mathrm{k}\right| \_61 \mathrm{k}-70 \mathrm{k} \mid \_$More than $\$ 70 \mathrm{k}$ |

7. What is the job title or role for the advertised position? (e.g. sales representative/ programmer/ teller etc.)

8. What level of English do you think is required for this job?

$\mid$ _ None $\mid \_$Basic $\mid \_$Intermediate |__Advanced |_Fluent $\mid \_$Must have English as a first language $\mid$ 
9. Please indicate which tasks you think English will be used for in this job:

\begin{tabular}{|l|l|l|l|l|}
\hline & Never & Sometimes & Often & Don't know \\
\hline Talking with colleagues casually & & & & \\
\hline Talking with clients casually & & & & \\
\hline Meeting formally with clients & & & & \\
\hline Writing emails & & & & \\
\hline Writing formal reports & & & & \\
\hline Reading emails & & & & \\
\hline Reading complex documents & & & & \\
\hline Other 1: & & & & \\
\hline Other 2: & & & & \\
\hline
\end{tabular}

10a. Is ability in languages other than English an asset in this job?

|_Yes $\mid$ _No (skip to question 10.)|

10b. How would other languages be used (e.g. communicating with colleagues, clients)? below.

$$
\text { 10c. Would any specific languages be of particular use in this position? Indicate language(s) }
$$

\section{ASSESSMENT OF ENGLISH ABILITY FOR THIS POSITION}

11. If you were evaluating the English ability of an immigrant applicant whose first language was not English, how would you rate the importance of the following evaluation methods?

\begin{tabular}{|l|l|l|l|l|l|}
\hline & $\begin{array}{l}\text { Not at all } \\
\text { important }\end{array}$ & $\begin{array}{l}\text { Somewhat } \\
\text { important }\end{array}$ & Important & $\begin{array}{l}\text { Very } \\
\text { important }\end{array}$ & $\begin{array}{l}\text { Don't } \\
\text { know/ NA }\end{array}$ \\
\hline Written test & & & & & \\
\hline $\begin{array}{l}\text { How strong I think their accent is during the } \\
\text { interview }\end{array}$ & & & & & \\
\hline How good their grammar is during the interview & & & & & \\
\hline Cultural background & & & & & \\
\hline How well they use English in their résumé & & & & & \\
\hline If their education was in English & & & & & \\
\hline $\begin{array}{l}\text { Successful completion of an English language } \\
\text { training course (e.g. ESL classes, TOEFL) }\end{array}$ & & & & & \\
\hline Other 1: & & & & & \\
\hline Other 2: & & & & & \\
\hline
\end{tabular}

12. If you were designing an English language training program specifically to help an immigrant applicant whose first language was not English qualify for this job, how much importance would you place on the following areas?

\begin{tabular}{|l|l|l|l|l|l|}
\hline & $\begin{array}{l}\text { Not at all } \\
\text { important }\end{array}$ & $\begin{array}{l}\text { Somewhat } \\
\text { important }\end{array}$ & Important & $\begin{array}{l}\text { Very } \\
\text { important }\end{array}$ & $\begin{array}{l}\text { Don't } \\
\text { know/ NA }\end{array}$ \\
\hline Focus on grammar & & & & & \\
\hline Focus on vocabulary & & & & & \\
\hline Focus on trying to sound more Canadian & & & & & \\
\hline Focus on writing & & & & & \\
\hline Focus on speaking comfortably & & & & & \\
\hline Focus on accent & & & & & \\
\hline Other 1: & & & & & \\
\hline Other 2: & & & & & \\
\hline
\end{tabular}


13. Please indicate your level of agreement with the following statements regarding immigrant applicants for this position:

\begin{tabular}{|c|c|c|c|c|c|}
\hline & $\begin{array}{l}\text { Strongly } \\
\text { disagree }\end{array}$ & Disagree & Neutral & Agree & $\begin{array}{l}\text { Strongly } \\
\text { agree }\end{array}$ \\
\hline $\begin{array}{l}\text { Someone who has a limited English vocabulary is } \\
\text { going to have a hard time convincing me to hire } \\
\text { them for this job }\end{array}$ & & & & & \\
\hline $\begin{array}{l}\text { Speaking skills are more important for this job } \\
\text { than writing skills }\end{array}$ & & & & & \\
\hline $\begin{array}{l}\text { I would consider hiring someone for this job even } \\
\text { if they had a strong foreign accent }\end{array}$ & & & & & \\
\hline $\begin{array}{l}\text { I would consider hiring someone for this job even } \\
\text { if they had limited writing ability as long as they } \\
\text { could speak English well enough }\end{array}$ & & & & & \\
\hline $\begin{array}{l}\text { Writing skills are more important for this job than } \\
\text { speaking skills }\end{array}$ & & & & & \\
\hline $\begin{array}{l}\text { I would only hire someone for this job whose first } \\
\text { language was standard English }\end{array}$ & & & & & \\
\hline $\begin{array}{l}\text { Even if someone could write reasonably well in } \\
\text { English, I would not hire them for this job if I } \\
\text { thought their accent made them difficult to } \\
\text { understand }\end{array}$ & & & & & \\
\hline
\end{tabular}

\section{WRAP-UP QUESTIONS}

14a. Have you ever received training on evaluating language ability?

$\mid$ _Y Yes |_No (skip to question 14.)|

14b. Please provide relevant details:

15. What is your mother tongue?

16. What other language(s) do you speak if any?

17a. Have you ever hired an immigrant whose first language was not English (i.e. you were responsible for the hiring decision)?

$\mid \_$Yes $\mid$_No (go to next page)|

17b. Please indicate (to the extent you can remember) what the positions were for (e.g. sales representative/ programmer/ teller etc.): 


\section{APPENDIX 2 \\ Ryerson University \\ Consent Information}

Research project: Labour Market Integration of Non-native English Speaking Immigrants

You are being asked to participate in a research study. Before you give your consent to take part by returning this survey, it is important that you read the following information to be sure you understand what you will be asked to do.

Investigators: This research project is being conducted by Alanna MacDougall in partial fulfilment of the requirements for Ryerson University's MA program in Immigration and Settlement Studies. Ms. MacDougall's faculty supervisor is Prof. Marco Fiola.

Purpose of the Study: This project is looking at the labour market integration of newcomers to Canada who speak English as a second language. Based on the results of this study, recommended strategies will be developed for evaluating language training programs geared at immigrants and other programs aimed at facilitating immigrants' entry into the Canadian labour market.

Description of the Study: If you agree to participate in this study, you will be asked to fill out the attached questionnaire about how you might evaluate the language ability of immigrants who apply for a specific job posting at your organisation, and return it in the pre-stamped envelope provided. The survey should take approximately 15-20 minutes to complete.

What is Experimental in this Study: The questionnaire used in this study is not experimental in nature. The only experimental aspect of this study is the gathering of information for the purpose of analysis.

Risks or Discomforts: If any personal discomfort arises due to the nature of or questions on the survey, subjects are reminded that their participation is completely voluntary and they may choose to end their participation at any time.

Benefits of the Study: Individual participants should not expect to receive direct benefits from this study. However, participation will lead to benefits for newcomers to Canada through the examination of how to facilitate their labour market entry, as well as for Canadian employers through the exploration of strategies for improving their access to qualified immigrant job candidates.

Confidentiality: Confidentiality will be maintained to the extent allowed by law. Respondents will remain anonymous unless they chose to self-identify. Respondents who self-identify will only be contacted by the researcher if follow-up questions are necessary. No individual identifying information will be included in the final research paper either about the respondent or his or her organisation. Responses will be viewed and coded by the researcher only. Responses will be destroyed after final submission of the research paper.

Incentives to Participate: Participants will not be paid to participate in this study.

Voluntary Nature of Participation: Participation in this study is voluntary. Your choice of whether or not to participate will not influence your future relations with Ryerson University. Once the completed survey has been mailed to the researcher, however, it will not be possible to withdraw your participation, as surveys contain no individually identifying information.

Questions about the Study: If you have any questions about the research please ask. You may contact.

Alanna MacDougall

alanna.macdougall@ryerson.ca

613.565 .5379

If you have questions regarding your rights as a human subject and participant in this study, you may contact the Ryerson University Research Ethics Board for information.

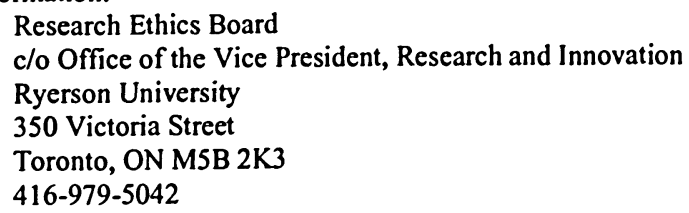

Agreement:

By completing and mailing this survey to the researcher in the stamped envelope provided, you are indicating that you agree to participate in the study. You are informed that by doing so, you are not giving up any of your legal rights. 


\title{
[address] \\ APPENDIX 3
}

July 5,2007

\section{Dear Sir or Madam,}

I am writing you with regard to position [position name], referenced as [reference number], posted on [job search website].

I am a graduate student at Ryerson University (Toronto) conducting research on the labour market integration of newcomers to Canada who speak English as a second language. As part of this research, I am conducting a survey of employers in Ottawa regarding methods used to determine the language ability of newcomers to Canada in the hiring process. Based on the results of this study, I hope to develop strategies for evaluating language training programs geared at immigrants and other programs aimed at facilitating immigrants' entry into the Canadian labour market.

This position has been randomly selected from a list of positions open at a major online job database within the Ottawa area, the region of my case study.

I would greatly appreciate if you could take a few minutes to fill out the survey attached on how you might evaluate the language ability of foreign-born applicants for this particular position. I assure you that any information provided will be kept confidential, and no identifying information will tie your response back to your organisation in my final report. Your response will also be destroyed upon completion of the research project. Additional information about the study is attached (see Consent Information).

This project has passed an ethics review process to ensure participant protection, and data collection methods have been evaluated and approved by the Ryerson University Research Ethics Board.

Thank you very much for helping further the study of immigrant labour market integration.

\author{
Alanna MacDougall \\ MA candidate \\ Immigration and Settlement Studies \\ Ryerson University \\ alanna.macdougall@ryerson.ca
}




\section{REFERENCES}

Baker, Colin (2003). Foundations of Bilingual Education and Bilingualism ( $3^{\text {rd }}$ ed.). Toronto: Multilingual Matters Ltd.

Cameron, Christopher David Ruiz (1997). How the Garcia Cousins Lost Their Accents. California Law Review, 85, 1347-1393.

Cargile, Aaron Castelan, \& Giles, H. (1998). Language attitudes toward varieties of English: An American-Japanese context. Journal of Applied Communication Research, 26, 338- 356.

Celce-Murcia, Marianne, Brinton, Donna M. \& Goodwin, Janet M. (1996). Teaching Pronunciation: A Reference for Teachers of English to Speakers of Other Languages. Cambridge: Cambridge University Press.

Citizenship and Immigration Canada (2006a). Facts and Figures. Retrieved August 10, 2007, from http://www.cic.gc.ca/english/pdf/pub/facts2006.pdf

Citizenship and Immigration Canada (2006b). Annual Report to Parliament on Immigration: 2006. Retrieved August 10, 2007, from http://www.cic.gc.ca/english/pdf/pub/immigration2006_e.pdf

Creese, Gillian \& Kambere, Edith (2003). What Colour is Your English? Canadian Review of Sociology and Anthropology, 40, 565-573.

Delamere, T. (1986). The Role of Stereotyping in Native Speaker Judgments of English as a Second Language Learners' Performance (Doctoral dissertation, Florida State University, Tallahassee, FL., 1986).

Derwing, Tracey \& Munro, Murray (1997). Accent, Intelligibility and Comprehensibility: Evidence from Four L1s. Studies in Second Language Acquisition, 19, 1-16.

Derwing, Tracey, Munro, Murray \& Wiebe, Grace (1997). Pronunciation instruction for "fossilized" learners: Can it help? Applied Language Learning, 8, 217-235.

Derwing, Tracey, Munro, Murray \& Wiebe, Grace (1998). Evidence in Favour of a Broad Framework for Pronunciation Instruction. Language Learning, 48, 393-410.

Derwing, Tracey \& Munro, Murray (2002). Teaching Native Speakers to Listen to Foreign-accented Speech. Journal of Multilingual and Multicultural Development, 23, 245-259. 
Derwing, Tracey (2003). What do ESL Students Say About their Accents? Canadian Modern Language Review, 59, 547-566.

Eisenhower, Kristina (2002). American Attitudes toward Accented English. Unpublished masters' thesis, McGill University, Montréal.

Gass, Susan, Varonis, Evangeline Marlos (1984). The Effect of Familiarity on the Comprehensibility of Nonnative Speech. Language Learning, 34, 65-89.

Giles, H., Williams, A., Mackie, D.M. \& Rosselli, F. (1995). Reactions to Anglo- and Hispanic-American-accented Speakers: Affect, Identity, Persuasion, and the English-only Controversy. Language and Communication, 15, 107-120.

Gill, Mary (1991). Accents and Stereotypes: Their effects on perceptions of teachers and lecture comprehension (Doctoral dissertation, University of Nebraska, 1991).

Green, David A. \& Worswick, Christopher (2004). Earnings of Immigrant Men in Canada: The Roles of Labour Market Entry Effects and Returns to Foreign Experience. University of British Columbia, Department of Economics. Paper prepared for Citizenship and Immigration Canada 2002, revised 2004.

Jongman, Allard, Wade, Travis \& Sereno, Joan (2003). On Improving the Perception of Foreign-accented Speech. In M.J. Sole, D. Recasens, and J. Romero (eds.) Proceedings of the 15th International Congress of Phonetic Sciences, 1561-1564.

Kasozi, A.B.K. (1986). The Integration of Black African Immigrants in Canadian Society: A Case Study of Toronto CMA. Toronto: Canadian-African Newcomer Aid Centre of Toronto.

Lindemann, Stephanie (2003). Koreans, Chinese or Indians? Attitudes and Ideologies about Non-native English Speakers in the United States. Journal of Sociolinguistics, 7, 348-364.

Lindemann, Stephanie (2005). Who speaks “broken English"? US undergraduates' perceptions of non-native English. International Journal of Applied Linguistics, $15,187-212$.

Lippi-Green, Rosina (1994). Accent, Standard Language Ideology, and Discriminatory Pretext in the Courts. Language in Society, 23, 163-198.

Lippi-Green, Rosina (1997). English with an Accent: language, ideology, and discrimination in the United States. New York: Routledge.

Lopes, Sandra (2004). Bringing Employers into the Immigration Debate. Ottawa: Public Policy Forum. 
Macdonald, Doris, Yule, George \& Powers, Maggie (1994). Attempts to Improve English L2 Pronunciation: The Variable Effects of Different Types of Instruction. Language Learning, 44, 75-100.

Matsuda, Mari (1991). Voices of America: Accent, Antidiscrimination Law, and a Jurisprudence for the Lat Reconstruction. Yale Law Journal, 100, 1329-1407.

Munro, Murray (2003). A Primer on Accent Discrimination in the Canadian Context. TESL Canada Journal, 20, 38-51.

Munro, Murray \& Derwing, Tracey (1995). Foreign Accent, Comprehensibility, and Intelligibility in the Speech of Second Language Learners. Language Learning, 45, 73-97.

Newman, W. Lawrence (2006). Social Research Methods: Qualitative and Quantitative Approaches. Boston: Pearson A and B.

Pawlikowska-Smith, Grazyna (2002). Canadian Language Benchmarks 2000:

Theoretical Framework. Ottawa: Centre for Canadian Language Benchmarks.

Prefontaine, Jean Paul \& Benson, Andrew (1999, January). Barriers to Canadian Immigrants' Economic Integration: Government Response to Market Failure. Paper presented at Third National Metropolis Conference, Vancouver BC.

Purcell, Edward T. \& Suter, Richard W. (1980). Predictors of Pronunciation Accuracy: A Reexamination. Language Learning, 30, 271-287.

Reitz, Jeffery (1999). Warmth of the Welcome: The Social Causes of Economic Success in Different Nations and Cities. Boulder: Westview Press.

Riches, Phoebe, \& Foddy, Margaret (1989). Ethnic Accent as Status Cue. Social Psychology Quarterly, 52, 197-206.

Rubin, D.L., DeHart, J., \& Heintzman, M. (1991). Effects of Accented Speech and Culture-Typical Compliance Gaining Style of Subordinates' Impressions of Managers. International Journal of Intercultural Relations, 15, 267-283.

Simpson, Brent \& Walker, Henry (2002). Status Characteristics and Performance Expectations: A Reformulation. Sociological Theory, 20, 24-40.

Spicher, Lori. (1992). Language Attitude towards Speakers with a Mexican Accent: Ramifications in the business community of San Diego, California (Doctoral dissertation, University of Texas, Austin, 1992).

Statistics Canada (2006, June 28). Service Industries. Retrieved August 10, 2007, from http://www41.statcan.ca/0163/ceb0163_000_e.htm 
2) $B L-1 E \cdot a b$ 